Article

\title{
Evaluating the Link between Low Carbon Reductions Strategies and Its Performance in the Context of Climate Change: A Carbon Footprint of a Wood-Frame Residential Building in Quebec, Canada
}

\author{
Alejandro Padilla-Rivera ${ }^{1, *}$ (i), Ben Amor $^{2}$ (i) and Pierre Blanchet ${ }^{1 \text { (i) }}$ \\ 1 NSERC Industrial Research Chair on Ecoresponsible Wood Construction, Département des Sciences \\ du Bois et de la Forêt, Université Laval, 2425 Rue de la Terrasse, Pavillon Abitibi-Price, \\ Québec, QC G1V 0A6, Canada; Pierre.Blanchet@sbf.ulaval.ca \\ 2 Interdisciplinary Research Laboratory on Sustainable Engineering and Ecodesign (LIRIDE), \\ Civil Engineering Department, Université de Sherbrooke, Sherbrooke, QC J1K 2R1, Canada; \\ ben.amor@liride.info \\ * Correspondence: Alejandro-de-jesus.padilla-rivera.1@ulaval.ca
}

Received: 16 July 2018; Accepted: 1 August 2018; Published: 2 August 2018

\begin{abstract}
The design and study of low carbon buildings is a major concern in a modern economy due to high carbon emissions produced by buildings and its effects on climate change. Studies have investigated (CFP) Carbon Footprint of buildings, but there remains a need for a strong analysis that measure and quantify the overall degree of GHG emissions reductions and its relationship with the effect on climate change mitigation. This study evaluates the potential of reducing greenhouse gas (GHG) emissions from the building sector by evaluating the (CFP) of four hotpots approaches defined in line with commonly carbon reduction strategies, also known as mitigation strategies. CFP framework is applied to compare the (CC) climate change impact of mitigation strategies. A multi-story timber residential construction in Quebec City (Canada) was chosen as a baseline scenario. This building has been designed with the idea of being a reference of sustainable development application in the building sector. In this scenario, the production of materials and construction (assembly, waste management and transportation) were evaluated. A CFP that covers eight actions divided in four low carbon strategies, including: low carbon materials, material minimization, reuse and recycle materials and adoption of local sources and use of biofuels were evaluated. The results of this study shows that the used of prefabricated technique in buildings is an alternative to reduce the CFP of buildings in the context of Quebec. The CC decreases per $\mathrm{m}^{2}$ floor area in baseline scenario is up to $25 \%$ than current buildings. If the benefits of low carbon strategies are included, the timber structures can generate 38\% lower CC than the original baseline scenario. The investigation recommends that $\mathrm{CO}_{2}$ eq emissions reduction in the design and implementation of residential constructions as climate change mitigation is perfectly feasible by following different working strategies. It is concluded that if the four strategies were implemented in current buildings they would have environmental benefits by reducing its CFP. The reuse wood wastes into production of particleboard has the greatest environmental benefit due to temporary carbon storage.
\end{abstract}

Keywords: carbon footprint; sustainable buildings; climate change; low carbon materials

\section{Introduction}

Concern about climate change and global warming have become a central issue in building policy decision-making. In 2010, the Intergovernmental Panel on Climate Change (IPCC) reported 
that buildings accounted for 32\% of total global energy use; and 19\% of total Greenhouse Gas (GHG) emissions [1]. Furthermore, they represent for approximately one third of black carbon emissions (REF) and one eight to one third of F-gas emissions.

In the other hand, the United Nations Environment Programme (UNEP) [2] has declared that due to rapid urbanization and the inefficiency of existing building stock, GHG emissions will be duplicated by 2030 unless mitigation strategies are implemented, therefore, GHG emissions reductions in the building sector is an important focus of research. To achieve the objectives set by IPCC, the development and use of adequate climate change mitigation strategies will play a pivotal and indispensable role [3,4].

The carbon footprint (CFP) has become a hot spot in environmental science and related academic fields in recent years [5]. In this sense, carbon footprint technique provides better understanding to represents the total set of GHG emissions caused directly or indirectly by an activity or resulting from the different life cycle stages of a product. Research on carbon footprints, therefore, is of special significance in dealing with climate change, especially in regions with high constructions rates, and the availability of affordable low-carbon materials that can be part of high performance buildings [6].

The studies reported in the literature for determining the carbon footprint has been studied for several years, including various strategies to reduce GHG emissions and mitigate climate change of buildings [7-10]. These approaches, are generally subdivided into four classes (1) low carbon materials, (2) material minimization and material reduction strategies, (3) material reuse and recycling strategies and (4) local sourcing and transport minimization [11]. These approaches are translated into decrements in cost, time, defects, health and safety risks, and a consequent increase in quality, predictability, whole-life performance and profitability [12-14].

However, even the most recent carbon footprint-based studies have shown efforts to reduce GHG emissions related to material embodied carbon (emissions related to construction, transportation and production of building materials) there remains a need for a strong analysis that measure and quantify the overall degree of GHG emissions reductions and its relationship with the effect on climate change mitigation [15]. Existing studies were mainly concentrated on energy consumption or building construction process. Therefore, efficient climate change mitigation strategies that assure low GHG emissions, feasible and environmentally friendly need to be addressed to current building practices to reduce the negative effect of GHG emissions and promote sustainable architectural planning. The term climate change mitigation strategy refers to the design, the equipment or procedure, which are developed to reduce the negative effect of GHG emissions.

The goal of this study is to describe and propose and evaluate carbon reduction strategies in the building sector by considering a wood-frame baseline building. Carbon footprint analysis, based on ISO 14067 (2013), was applied to assess the strategies in order to quantify the overall potential of reducing GHG emissions. Our study deals with the link between low carbon reductions strategies and its performance in the context of climate change. The GHG emissions evaluated include the production of buildings materials and construction of buildings, considering all necessary transport activities.

The obtained results should enable to target the specific sources of GHG emissions in the production phase and construction phase and establish knowledge for building professionals such as engineers, architects and interior designers for developing guidelines to improve efficiency and competitiveness through environmental innovations in processes and products.

\section{Conceptual Framework and Methods}

\subsection{Carbon Footprint Approach}

Normally, CFP calculation associates to the six GHGs identified in the Kyoto Protocol $\left(\mathrm{CO}_{2}, \mathrm{CH}_{4}\right.$, $\mathrm{N}_{2} \mathrm{O}, \mathrm{SF}_{6}, \mathrm{HFC}$ and PFCs) [16]. The global warming potential (GWP) of GHGs is the ratio between the heating caused by the specific GHG over a specific time interval and heating caused over the same 
period by an equal amount of carbon dioxide $\left(\mathrm{CO}_{2}\right)$ [17], which is used as reference gas and usually expressed as equivalent carbon dioxide $\left(\mathrm{CO}_{2}-\mathrm{e}\right)$ [18].

All over this paper, the term CFP is used to refer to GHG emissions of building materials during the processes of production, on-site construction, transportation and disposal. To facilitate comparison and reporting $\mathrm{CO}_{2}$-e is used to quantify and report the overall GHG emissions emitted during a process.

In order to estimate GHG emissions produced in the building processes and its repercussion in climate change mitigation we followed the recommendations of technical specification principles of the Carbon of Footprint of Products (CFPs) of ISO 14067 series [19]. The quantification and reporting of a CFP in accordance with technical specifications of ISO 14067 series is based on the principles of the Life Cycle Assessment (LCA) methodology provided in ISO 14040-14044. When assessing the carbon footprint, it is important to define the scope. In this sense, CFPs stablishes the following scopes to quantify the CFP:

- Scope 1-occur from sources that are owned or controlled by the company, also referred to as direct GHGs;

- Scope 2-emissions from the generation of purchased electricity consumed by a company, also referred to as energy indirect GHGs;

- Scope 3-emissions that are a consequence of the activities of the company but occur from sources not owned or controlled by the company, cradle to end of life approach, also referred to as other indirect GHGs.

\subsection{Carbon Footprint of Base Scenario}

This section describes the case study building that was analyzed and the methods used to determine the carbon footprint for this building. The methodology followed five main stages reflecting the scopes of this research, the methodology followed is summarized in Figure 1.

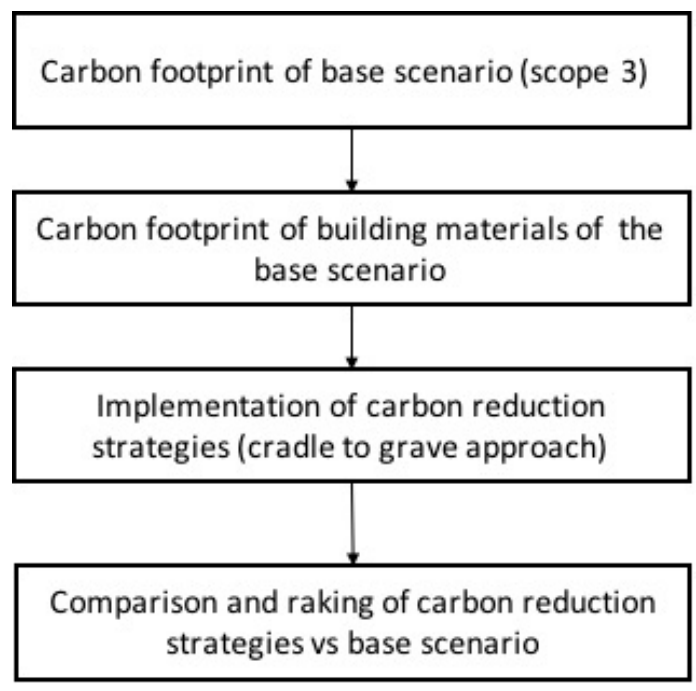

Figure 1. Summary of the study's methodology.

The scope 3 approach (ISO, 14067) was used to assess and report environmental impacts of a products life cycle through the raw material production, manufacture, distribution, use and disposal including any necessary or induced intermediate transportation steps. This evaluation includes all side stream releases to the air, water, and soil. Life Cycle Assessment (LCA) is an attempt to comprehensively describe all these activities and the resulting environmental release and impacts. In order to carry out this research and to quantify GHG emissions, the recommendations of the ISO 14040 series [20] were followed. This CFP study has been modeled using Open LCA 1.5.0 software 
(Berlin, Germany). All data are collected from the Société d'habitation du Québec (SHQ), the Province of Quebec Social Housing Agency [21].

The CFP emissions from base scenario was taken from Ecoinvent 3.0 database of each different building materials production. These emissions are generated by the building life-cycle process, from raw materials to transportation and production. It is calculated as follows:

$$
\mathrm{CFP}_{1}=\sum_{i=1}^{n}\left(M_{1 i} \times C E_{1 i}\right)
$$

where $\mathrm{CFP}_{1}$ indicates the carbon footprint from buildings materials production, including timber, insolation materials, steel, doors, windows etc.; $M_{1 i}$ is the use amount of building material type $i$; $C E_{1 i}$ is the carbon emissions by producing per $\mathrm{kg}$ of building material type.

\subsubsection{Case Study Building}

A multi-storey building in Quebec City has been used as reference to model the wood-frame building system explored in this study a case study. The building selected is part of a $93,000-\mathrm{m}^{2}$ area located on the lands of the Cité Verte, in the Saint-Sacrement district of Quebec City, Canada. This residential complex, consisting of condominiums, townhouses and offices and businesses, aims to integrate sustainable development elements from the design and exploitation of energy management, waste management, transportation and construction techniques. (Figure 2)

The reference building is a mass timber prefabricated structure residential building. It is a four-story building and contains a total of 20 apartments with a total living area of $1512.3 \mathrm{~m}^{2}$ (75 $\mathrm{m}^{2}$ per unit). The multi-residential building currently employs biomass district heating system for its space heating and domestic hot water needs, storm water management to reduce energy use associated with water, and innovative planning to encourage alternative modes of transportation.

According to Environment and Natural Resources Canada [22] Quebec City has humid continental climate with four distinct seasons having very warm and humid summers with average temperatures from around 25 degrees Celsius and often very cold with many windy days and snow in winter. The principal climate influences are mainly of storm systems from the core of North America and the Atlantic Ocean, precipitation is very abundant all the year.

\section{Prefabrication}

Prefabrication is construction method that refers to the transfer of on-site construction work from sites to factories. Normally, the method includes the control of manufacturing building components, the transportation of entire or partial components to the construction site, and the installation of pre-assembled components to create new constructions [23]. Prefabrication can be divided into three types: semi-prefabricated (some parts are fabricated in situ); fully prefabricated (all buildings components prefabricated and assembled in situ); and modular building, which is fully build in factory [24]. Different benefits are produced by using prefabrication, including, better quality product, lower costs, and shorter construction time. Another important benefit is the fact that prefabrication is independent of weather conditions and on-site accidents are reduced; site wastes and GHG emissions are also reduced [25].

\subsubsection{Functional Unit and System Boundary}

In LCA, the functional unit provides a reference to which the inputs and outputs are related. According to Anand \& Amor [26] different functional units could be used in buildings LCA. These units are based on floor area, volume, mass or building elements, depending on the goal of the LCA. Results should be representative of all the impacts from a building as a whole. Thus, in order to establish a baseline to evaluate the prefabricated building and to make comparison, the functional unit for this study is defined as providing $1 \mathrm{~m}^{2}$ of floor area for residential purposes. 
System boundaries show the life cycle stages included in this analysis. Cradle to grave is the most popular system boundary adopted in buildings [27]. Since the focus on this research is the calculation of embodied carbon emissions, the construction of buildings, the process of manufacture, delivery and assembly of the components are included in the system. Therefore, use and demolition and final disposal are not considered (i.e., a cradle-to-gate LCA). The system boundary of this study is shown in Figure 2.

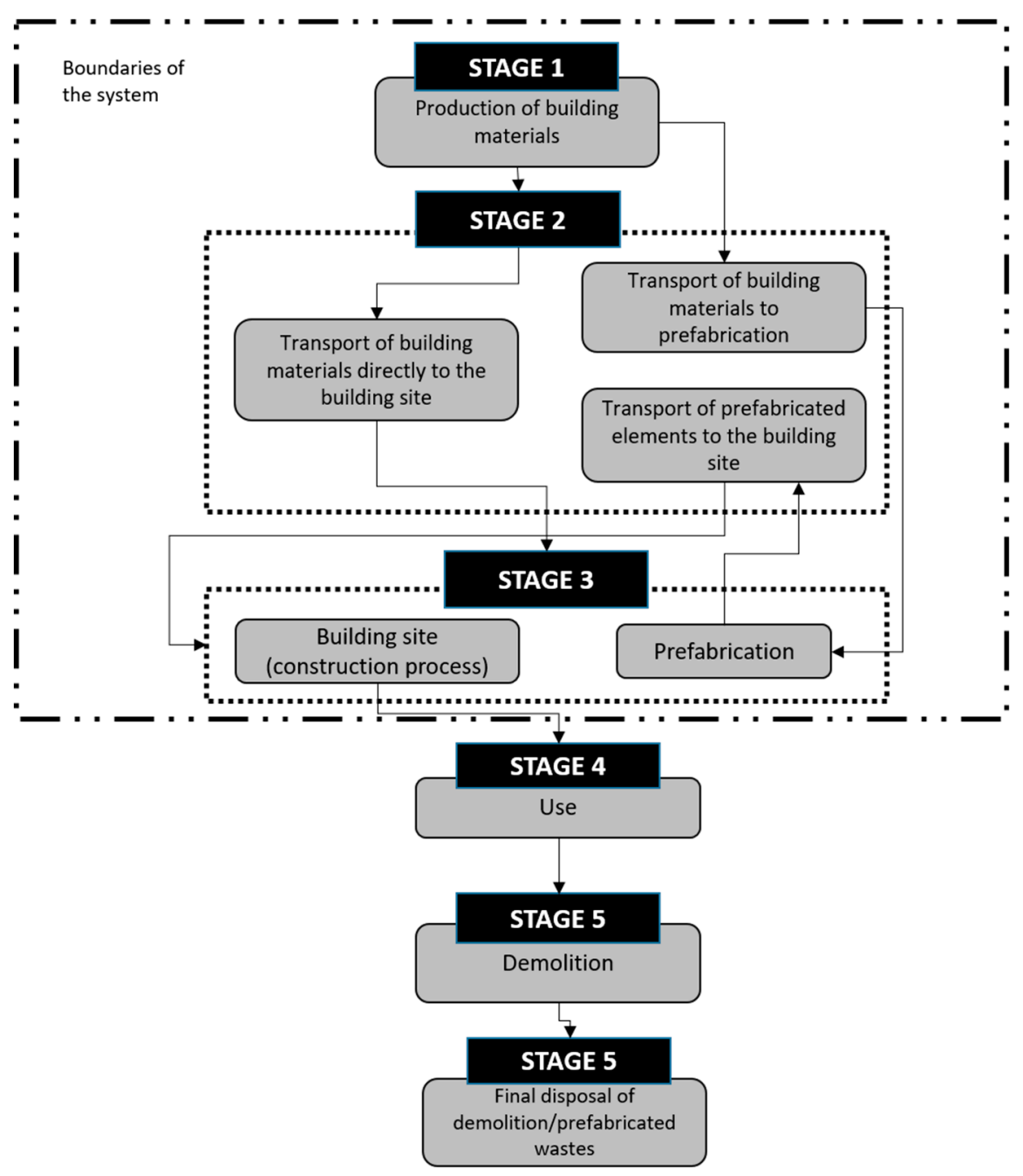

Figure 2. System boundary for $1 \mathrm{~m}^{2}$ of floor area (cradle to gate).

First, the material acquisition comprises activities such as harvesting, extracting and mining of raw materials (iron ores, bauxite, wood, petroleum and etc.). The material production includes the phase in which the raw materials are converted into engineered products usable for a certain proposed purpose.

\subsubsection{Life Cycle Inventory}

The assessment of material and energy consumption (including transportation) for this phase utilizes inventory database from Ecoinvent v3.1 [28] The inventories from this database were selected for all analysed stages. The study was carried out according to a static focus, so the life cycle inventories include intermediate values of the current processes within the system analyzed, without analyzing their variation over time. 
The installation of the prefabricated building and site-work are accounted for site/assembly phase. This phase accounts for site-work including assembly of the processed materials (including lumber, plywood, concrete, windows and steel) and energy, excavation, footing installation and other earthworks. This phase includes the modular building installation when each completed module of the building is transported to the building site. In parallel the construction waste management is taken into consideration. All materials were assumed to be sent to a landfill.

Transportation is separated into two categories: material transportation (site fabrication to site assembly) and module transportation (site assembly to site construction). The material transportation is the transportation required for moving materials between each phase, such as transporting raw materials for the material processing. All material's transportation is traced from where the building materials are processed and manufactured to the final materials that are eventually installed in the building. The module transportation is the delivery process of the completed modular building, from the fabrication site to the building site.

Life Cycle Inventory (LCI) To carry out the inventory, primary data were collected mainly from the SHQ, either directly by fieldwork or by bibliographical sources. When primary data were not available, the unit processes were selected from the Ecoinvent v3.1 and open databases, the most comprehensive Life Cycle Inventory database currently available. The LCI component identifies and quantifies the material and energy resource inputs as well as the emissions and product outputs from the unit processes in accordance with the functional unit and boundaries. The LCI is an iterative process that requires time and amount of research, fortunately the use of databases help in the process. The U.S Life Cycle Inventory Database, developed by National Renewable Energy Laboratory, and Ecoinvent V3.1 database, which has been developed by a Swiss initiative haven been selected as a reference in this study. All the unit processes selected in this database were cradle-to grave processes. All upstream processes are linked in current unit processes, covering the cradle-to-gate boundaries of the system. A report from the SHQ on sustainable building has been used for the modelling this research [29]. For the current study, Table 1 shows the main construction materials with the respective quantities and processes used for the prefabricated building construction. In order to estimate the quantities (Table 1) per functional unit, calculations were related to physical properties, such as density or dimensions of the materials. The data was transformed from total area quantities $\left(75 \mathrm{~m}^{2}\right.$ per unit) to $1 \mathrm{~m}^{2}$ of building. As mentioned before raw data were obtained from reports and constructors [29]. 
Table 1. Principal materials, quantity and sources used in each stage evaluated.

\begin{tabular}{|c|c|c|c|c|}
\hline Life Cycle Stage & Material/Process & Quantity (per $1 \mathrm{~m}^{2}$ of Building & CFP Emissions ( $\mathrm{kg} \mathrm{CO}_{2}$-e) & Source of Data \\
\hline \multirow{22}{*}{$\begin{array}{l}\text { Material acquisition and } \\
\text { material production }\end{array}$} & Cross Laminated Timber (CLT) & $0.27 \mathrm{~m}^{3}$ & 21.00 & Ecoinvent v3.1 modified (Quebec context) \\
\hline & Glue laminated & $0.0019 \mathrm{~m}^{3}$ & 0.92 & Ecoinvent v3.1 \\
\hline & Steel & $3.98 \mathrm{~kg}$ & 10.68 & Ecoinvent v3.1 \\
\hline & Gypsum fiberboard & $4.92 \mathrm{~m}^{2}$ & 7.97 & Ecoinvent v3.1 \\
\hline & Concrete & $0.15 \mathrm{~m}^{3}$ & 44.08 & Ecoinvent v3.1 \\
\hline & Vinyl boards & $3.15 \mathrm{~kg}$ & 72.35 & Ecoinvent v3.1 \\
\hline & Granite & $3.88 \mathrm{~kg}$ & 0.54 & Ecoinvent v3.1 \\
\hline & Ceramic tiles & $1.83 \mathrm{~kg}$ & 1.47 & Ecoinvent v3.1 \\
\hline & Primer & $0.499 \mathrm{~kg}$ & 0.93 & Ecoinvent v3.1 \\
\hline & Paint & $1.35 \mathrm{~kg}$ & 3.91 & Ecoinvent v3.1 \\
\hline & Bricks & $50.23 \mathrm{~kg}$ & 12.02 & Ecoinvent v3.1 \\
\hline & Windows & $0.03 \mathrm{~m}^{2}$ & 0.61 & Ecoinvent v3.1 \\
\hline & Metal doors & $0.06 \mathrm{~m}^{2}$ & 3.36 & Ecoinvent v3.1 \\
\hline & Wooden doors & $0.30 \mathrm{~m}^{2}$ & 16.06 & Ecoinvent v3.1 adapted from US LCI \\
\hline & Fiberglas & $1.72 \mathrm{~kg}$ & 4.58 & Ecoinvent v3.1 \\
\hline & Insulation EPS & $1.15 \mathrm{~kg}$ & 1.05 & Ecoinvent v3.1 \\
\hline & Rigid polyisocyanurate insulation & $0.0560 \mathrm{~kg}$ & 0.29 & Ecoinvent v3.1 \\
\hline & Spray polyurethane & $0.06 \mathrm{~kg}$ & 0.29 & Ecoinvent v3.1 \\
\hline & Elastomeric membrane & $0.28 \mathrm{~kg}$ & 1.27 & Ecoinvent v3.1 \\
\hline & Coverage bitumen membrane & $0.08 \mathrm{~kg}$ & 0.09 & Ecoinvent v3.1 \\
\hline & Copper & $1.01 \mathrm{~kg}$ & 1.94 & Ecoinvent v3.1 \\
\hline & $\begin{array}{l}\text { Transportation to site assembly (Distance range: } 250 \text { for local } \\
\text { materials (wood, concrete) and } 500 \mathrm{~km} \text { for other materials) }\end{array}$ & $188.81 \mathrm{t}-\mathrm{km}$ & 36.70 & Ecoinvent v3.1 \\
\hline \multirow{13}{*}{ Assembly } & Electricity & $85.65 \mathrm{kwh}$ & 0.73 & Created (SHQ, 2016) \\
\hline & Excavation & $0.0264 \mathrm{~m}^{3}$ & 0.013 & Ecoinvent $\mathrm{v} 3.1$ \\
\hline & Diesel & $0.9919 \mathrm{kwh}$ & 0.33 & Ecoinvent v3.1 \\
\hline & Transportation from site construction to landfill $(25 \mathrm{~km})$ & $0.60 \mathrm{t}-\mathrm{km}$ & 0.479 & Ecoinvent v3.1 \\
\hline & $\begin{array}{l}\text { Waste Management ( } 25 \mathrm{~km} \text { is considered from site assembly to } \\
\text { landfill) (WM) (wood) }\end{array}$ & $9.91 \mathrm{~kg}$ & 14.52 & Ecoinvent v3.1 \\
\hline & WM (gypsum) & $5.26 \mathrm{~kg}$ & 0.076 & Ecoinvent v3.1 \\
\hline & WM (Iron metals) & $6.11 \mathrm{~kg}$ & 0.37 & Ecoinvent v3.1 \\
\hline & WM (Non-iron metals) & $1.97 \mathrm{~kg}$ & 0.014 & Ecoinvent v3.1 \\
\hline & WM (plastic) & $0.1656 \mathrm{~kg}$ & 0.015 & Ecoinvent v3.1 \\
\hline & WM (carton/paper) & $3.83 \mathrm{~kg}$ & 5.13 & Ecoinvent v3.1 \\
\hline & WM (insulation wool) & $0.4228 \mathrm{~kg}$ & .003 & Ecoinvent v3.1 \\
\hline & WM (Polythene) & $3.46 \mathrm{~kg}$ & 10.39 & Ecoinvent v3.1 \\
\hline & WM Transportation $(25 \mathrm{~km})$ & $0.6298 \mathrm{t}-\mathrm{km}$ & 0.82 & Ecoinvent v3.1 \\
\hline
\end{tabular}


Materials Acquisition and Material Production

The collected data for this life cycle stage under study is about the quantities, dimensions, and provenance of all materials used to build the building, these quantities are mainly extracted from the plans and specifications (Table 1). The stage included all the process for fabrication of materials (acquisition and production) as well as the transportation distances from manufacturing plant to the site of assembly. It was considered two different distances: $510 \mathrm{~km}$ for wood (CLT and glue laminated), $250 \mathrm{~km}$ for concrete and $500 \mathrm{~km}$ for the rest of materials.

\section{Assembly}

This section describes the construction techniques and equipment that have been used on-site assembly for prefabricated components, including the use of fuels for construction machines, transportation of materials and workers, and primary energy for building construction. The energy consumption was separated into two data sources: electricity consumption supplied by the contractor and fuel consumption derived from the literature, in the absence of information from the contractor. The material losses (wastes) are calculated from the characterization of sites of containers and quantification of materials extracted from the plans and specifications. Based on the material losses reported by SHQ in 2016, the wastes from the fabrication process are approximately ranging from $8 \%$ to $125 \%$ ( $11 \%$ average waste factor) of the overall materials used. For the transportation and final disposal of wastes is assumed a $50 \mathrm{~km}$ distance to landfill facilities.

Transportation from an off-site factory to the construction site is an important process in the assembly. In this base case the assembly and the site of construction is occurring in Quebec City. Material transportation highly depends on the distance of material supply chain. Unlike that in conventional building material transportation, prefabrication logistically requires a careful control process, as well as additional protection to avoid possible damage during transportation. It is assumed that in this study, a high-load truck is used as the major vehicle type for transportation, particularly when considering the large volume and weight of prefabricated components. The boundary of material transportation suppliers of building material shown in Table 1, materials for detailed indoors are beyond the scope of this study.

\subsubsection{Life Cycle Impact Assessment (LCIA)}

The third phase of a life cycle assessment, after LCI, is life cycle impact assessment. According to ISO 14040 [30], the mandatory steps in life cycle impact assessment are category definition, classification and characterization. Category definition consists of identifying which impact categories are relevant for the product being studied. Classification consists of grouping related substances into impact categories. For example, the gases $\mathrm{CO}_{2}$, methane, and $\mathrm{N}_{2} \mathrm{O}$ contribute to climate change; so, they can be grouped together in the impact category, climate change. The method chosen for evaluating the GHG emissions for this study is the IPCC 2013, which is an update method for IPCC 2007 developed by International Panel on Climate Change [1].

\subsubsection{Characterization Factor of Biogenic Carbon in LCA}

According to the guidelines compiled by the Intergovernmental Panel on Climate Change (IPCC), $\mathrm{CO}_{2}$ emission from bioenergy sources should not be counted in national greenhouse gas inventories because the emission from bioenergy sources is already fully included in the Agriculture, Forestry and Other Land-Use (AFOLU) sector [31]. In this sense, due to the assumption of zero climate change potential of biomass combustion, the methods for assessing its global warming impact in environmental analysis tools usually do not include the biogenic $\mathrm{CO}_{2}$ emission and even treat biogenic $\mathrm{CO}_{2}$ emission has negative impact. However, several recent studies have estimated $\mathrm{CO}_{2}$ emissions factors derivate from biomass, their estimates of characterization factors of biogenic carbon fell in the range of $0.34-0.62[32,33]$. The application of biogenic characterization factors is straight forward. 
These factors can be considerably lower than 1, implying and advantage of bioenergy compared to fossil fuels in a climate change perspective. Consequently, in this study the global warming effect of biogenic is considered to be carbon neutral.

\subsection{Description of Carbon Reduction Strategies}

In order to investigate the sensitivity of embodied carbon emissions from this building, design configuration was changed through a hypothetical way. Four hotspots approaches were defined and evaluated in line with the commonly carbon reduction strategies stablished in current research. They were conducted to single out those having the greatest potential for reducing environmental impact in baseline scenario. The strategies were evaluated following LCA approach, describe in Section 2.2 and taking the references in Table 2.

These strategies are divided and described into the following categories: (1) low carbon materials, (2) material minimization, (3) reuse and recycling strategies and (4) local sourcing and transport minimization. (Table 2). Each category has specific actions and modifications that impact in the embodied carbon of base scenario.

Table 2. Implementation and comparison of carbon reduction strategies of baseline scenario.

\begin{tabular}{|c|c|c|c|}
\hline Carbon Reduction Strategies & Actions & Modifications & Reference \\
\hline \multirow{4}{*}{ Low carbon materials } & Substitution of thermal materials & Cellulose insulation (recycled newsprint) & [34] \\
\hline & Substitution of alternative flooring types & Hardwood flooring system & [35] \\
\hline & Use of low-carbon bricks & $\begin{array}{l}\text { Use of Lower Clay-Lime-GGBS } \\
\text { (GGBS-Ground Granulated Blast-furnace } \\
\text { Slag) unfired brick types }\end{array}$ & [36] \\
\hline & $\begin{array}{l}\text { Replacement of cement concrete }(100 \% \\
\text { OPC) by combination of by-products }\end{array}$ & $\begin{array}{l}\text { New concrete mix } 70 \% \text { OPC }+30 \% \text { F.A } \\
\text { (OPC-Ordinary Portland Cement, FA-Fly } \\
\text { ash, NA-Natural Aggregate, RCA-Recycled } \\
\text { crush aggregate, NS-Natural sand). } \\
60 \% \text { N.A. }+40 \% \text { RCA } \\
100 \% \text { N.S }\end{array}$ & [37] \\
\hline Material minimization & Reduction of low waste ratios & $\begin{array}{l}\text { Wood } 7 \% \\
\text { Concrete } 7 \% \\
\text { Steel } 7 \%\end{array}$ & [38] \\
\hline Reuse and recycle materials & $\begin{array}{l}\text { Use of wood waste materials to produce } \\
\text { new materials }\end{array}$ & $\begin{array}{l}\text { Production and carbon storage in particleboard } \\
\text { of wood wastes }(7 \%)\end{array}$ & [39] \\
\hline \multirow{2}{*}{$\begin{array}{l}\text { Local sourcing and use } \\
\text { of biofuels }\end{array}$} & Use of local materials & Change of transportation distance $(50 \mathrm{~km})$ and & [8] \\
\hline & Use of biodiesel (B20) for transportation & $\begin{array}{l}\text { Implementation of biodiesel as a fuel for on-site } \\
\text { machines (blend mix B20) }\end{array}$ & {$[40]$} \\
\hline
\end{tabular}

\section{Results and Discussions}

\subsection{CFP of the Baseline Scenario}

Total $\mathrm{CO}_{2}$-e emissions are presented as the embodied carbon emissions per $1 \mathrm{~m}^{2}$ of floor building. All CFP emissions were calculated with the characterization factors from Ecoinvent 3.0 (Table 1) and used Equation (1). The estimated carbon emissions of the building material manufacturing phase and construction process was $275 \mathrm{~kg} \mathrm{CO}_{2}-\mathrm{e} / \mathrm{m}^{2}$. The raw material extraction, material production, including transportation account for $243 \mathrm{~kg} \mathrm{CO}_{2}$-e (88\% of the total). The assembly, that includes the modular fabrication, and construction waste management is $32 \mathrm{~kg} \mathrm{de} \mathrm{CO}_{2}$-e (12\%). If we see the contribution from the all the sub-process in the two life cycle stages, the fabrication of materials is responsible for $75 \%$ of total GWP, transportation to site construction $13 \%$, waste management $11 \%$ while the excavation, electricity and diesel accounts only for $1 \%$. Similar studies were noticed in other studies in Canada, Canada Wood Council, Société d'habitation du Québec and Lessard [29,41,42] that conducted life cycle analysis of different buildings structures frames (timber frame, steel and concrete) in Quebec, shown in Figure 3.

Findings suggest that the emissions of fabrication materials are the principal contributor to total GHG emissions in the five buildings, following by assembly phase. According to the results, the wood 
frames causes lower carbon emissions than concrete and steel frames. The baseline building presents significantly lower embodied $\mathrm{CO}_{2}$-e emissions $\left(275 \mathrm{~kg} / \mathrm{m}^{2}\right)$ compared to the wood frame $1\left(302 \mathrm{~kg} / \mathrm{m}^{2}\right)$ and wood frame $2\left(287 \mathrm{~kg} / \mathrm{m}^{2}\right)$, while concrete frame $\left(442 \mathrm{~kg} / \mathrm{m}^{2}\right)$ and steel frame $\left(353 \mathrm{~kg} / \mathrm{m}^{2}\right)$ are the greatest carbon contributors. The principal difference was mainly to the material frame and thus the higher embodied carbon emissions in concrete frame and steel frame. Similar results are presented for the remaining wood frame structures.

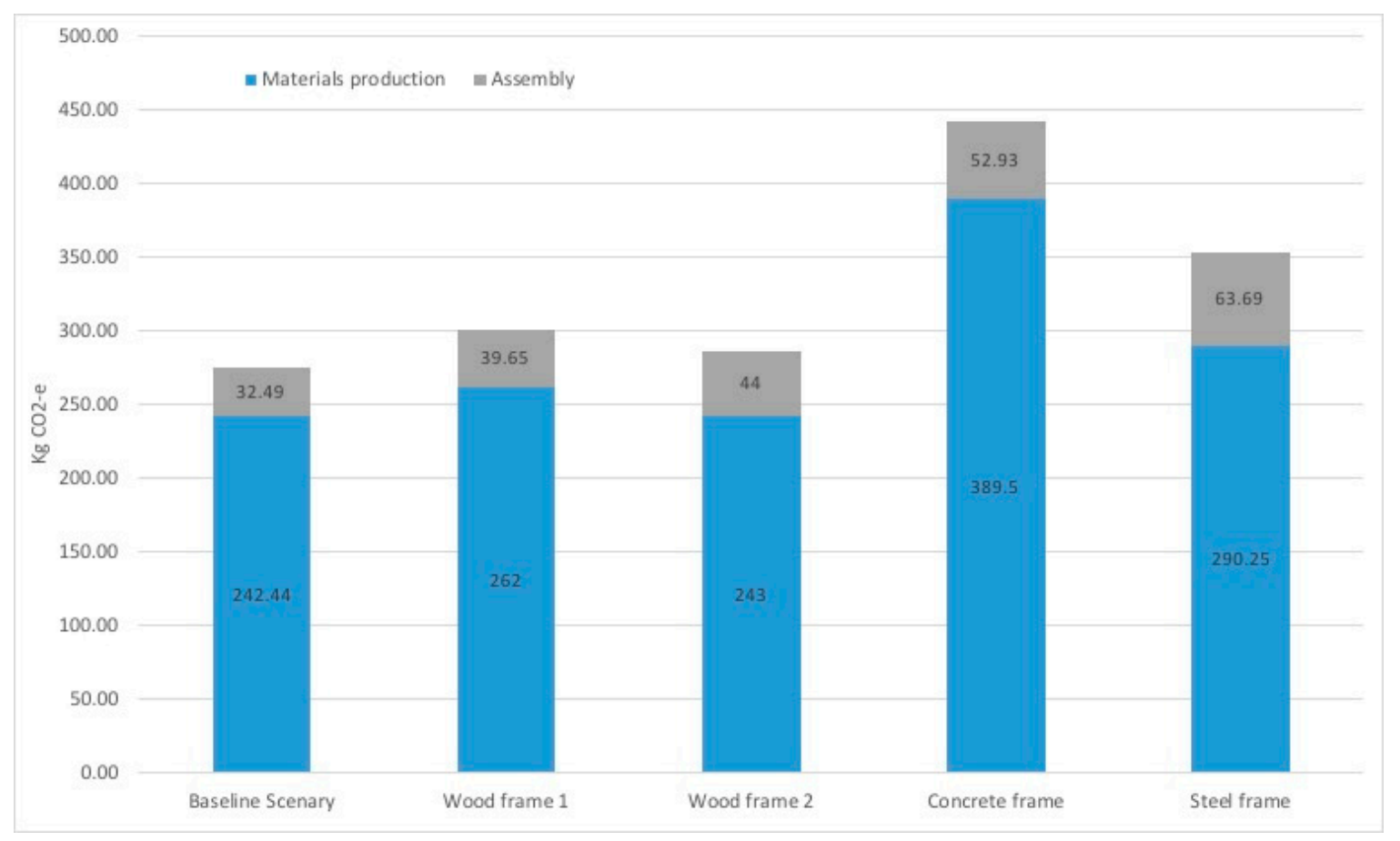

Figure 3. Embodied GHG emissions $\left(\mathrm{kg} \mathrm{CO}_{2}-\mathrm{e} / \mathrm{m}^{2}\right)$ in different Quebec buildings. (COLOR).

\subsection{Carbon Footprint of Buildings Materials}

When considering the materials building, they were grouped and aggregated to simplify the analysis. Furthermore, all bio-based materials (CLT and glue laminated timber) are included as part of the "wood and wood materials", gypsum, plaster board, paints, ceramic, as coating and substrate, and isolations, Expanded Polystyrene (EPS), cellulose and elastomer as insulation and sealing materials.

The percentage of materials for the systems in terms of building elements can be observed in Figure 4 . From the total building materials emissions (75\%), $28 \%$ are due to insulation and sealing components, it should be noticed that the impact of conventional insulation materials, as baseline building with a high level of industrial processing — such as EPS—is clearly higher than the impact of natural materials such as cork, wood fiber and sheep's wool, or recycled ones such as cellulose fiber [43]. So, while EPS insulation or polyurethane produces emissions on average $3.5 \mathrm{~kg} \mathrm{CO}_{2}$-e/ $\mathrm{kg}$ with high consumptions of fossil fuels, some insulation materials such as sheep's wool, could reduce its impact up to $98 \%$. 


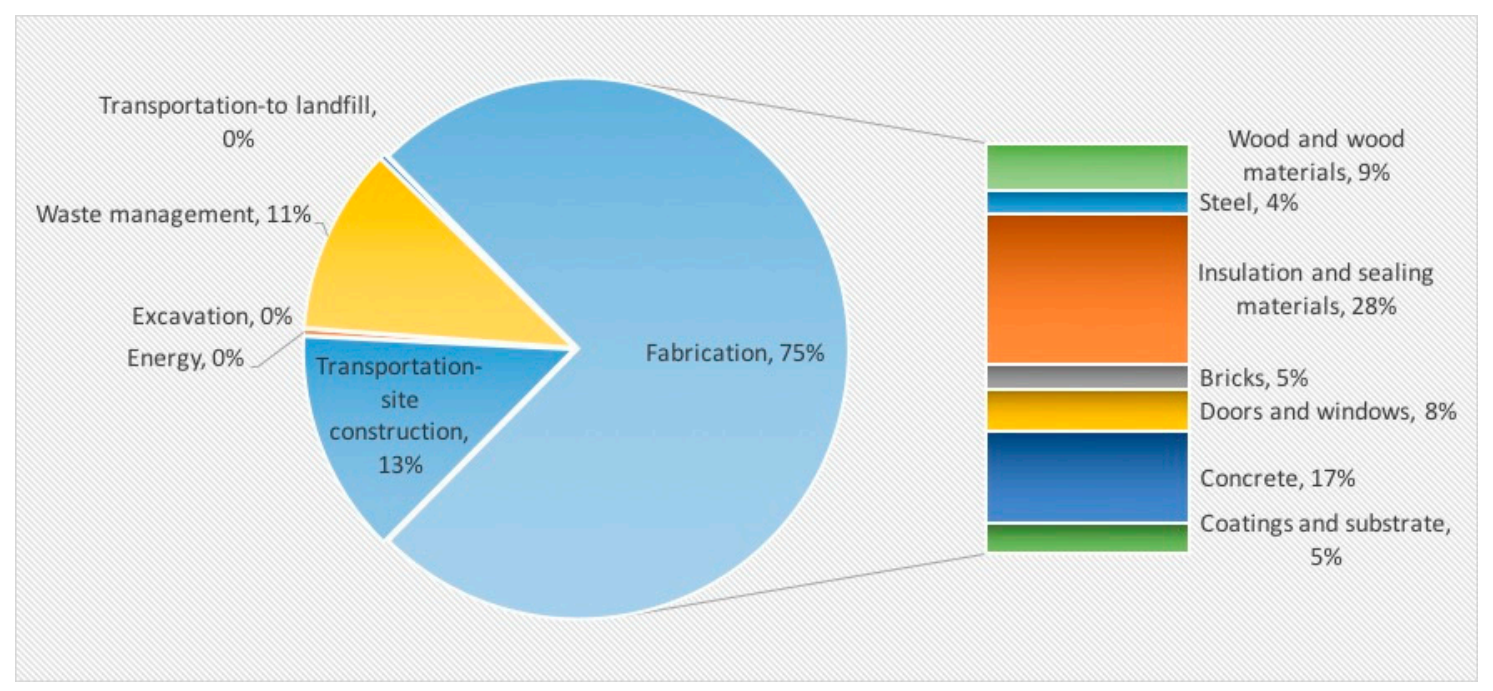

Figure 4. Contribution (\%) per sub-process of building materials in baseline scenario. (COLOR).

The impact of concrete (15\%) is an important element to pay attention, the high density of these material typically between $40-60 \%$ of the total weight of a conventional building, increases their CFP. According to multiple studies such as Güereca [44], the effect of the clinker manufacturing process on the life cycle of all the products that use cement is highly significant, thus in order to lower the impact of these products it is fundamental to reach a more eco-friendly production of cement, that can be made for the replacement of conventional fossil fuels with alternative fuels base on wastes for the clinker manufacturing process.

Regarding to wood materials, the contribution to GWP was of $15 \%$. However it is well known $[45,46]$ that materials used in construction based on timber has a lower GHG impact than many others, principally those components such as concrete or steel that require great amounts of energy for their industrial processing. An important aspect that it must be considered is the use of resins, the replacement of aldehyde compounds for natural resins could bring many positive impacts, the most important the reduction of $\mathrm{CO}_{2}$-e emissions.

Natural resins like Copa, Dammar, Mastic and Venice turpentine have a wide variety of uses in building industry ranging from sealants to cover the cracks in timber, in varnishes, paints or lacquers to create a hard, smooth, impermeable surface and as solvents such as turpentine for architectural purposes [47].

The fabrication of bricks contributes to GWP in $4 \%$, this kind of materials use big quantities of fossil fuels energy and clay during their manufacture stage, which means very labor-intensive as well as environmentally degrading. According to Kumbhar [48], the kiln process contributes up to $80 \%$ of total GHG emissions. One way to reduce this impact is the use of Green bricks that are composed of $80-85 \%$ clay and remaining organic material along with $10-12 \%$ of moisture content. Therefore, the organic material such as bagasse and rice husk used as a binding material in green bricks and used as fuel for internal combustion of green brick in kiln could reduce considerately the GHG emissions of bricks.

Finally, the steel fabrication represents $4 \%$ of total GWP impact, based on the life cycle activities associated with Blast furnace operations that contribute substantially to climate change in over $40 \%$ of total GWP. The improvement of currently implemented technologies or investment should be made in newer innovative steelmaking approaches such the use of larger amounts of direct injected coal or the injection of other types of fuel into the blast furnace that may reduce by $50 \%$ the use of coke and by $30 \%$ the use of energy [49]. 


\subsection{Implementation of Carbon Reduction Strategies}

\subsubsection{Material Recycle and Reuse Benefits}

The potential material resource and embodied carbon savings possible from the reuse and recycle for wood waste buildings are shown in Table 3, based on assumptions of the likely waste wood quantities available for reuse. According to Aye [50] the potential reuse of a material can never be guaranteed, but this study emphases the reuse of waste wood into production-and-use of particleboard, so, it makes sense to allocate environmental credit to waste wood management. It should be noted that these assumptions include the direct us of wood waste for manufacturing process of particleboard (A), the avoided impact from raw material use (B), the carbon storage $(C)$ and finally the environmental credit (A-B-C).

The reuse of even a small proportion (by volume) of waste wood at construction process can result in a substantial saving in embodied carbon for prefabricated timber systems, as this baseline case. The proportion of embodied carbon emissions able to be save by reusing wood waste into production-use of particleboard is up to $14.6 \%\left(-28.6 \mathrm{~kg} \mathrm{CO}_{2}-\mathrm{e} / \mathrm{m}^{2}\right)$. The production, use and recycle of particleboard reduce more greenhouse gases than the process using raw materials. Therefore, the net carbon of recycling wood waste was negative. In other words, using wood waste effectively produced an environmental benefit due to carbon storage of wood products. The recycling process of wood waste should be prudentially used over other uses of wood waste such landfill or energy recovery [39].

\subsubsection{Local Sourcing of Materials and Components and Adoption of Biofuels}

\section{Local Materials}

In Section 3.2 was showed the importance of transportation to the CFP of buildings. The principal factors influencing transportation emissions consist of the quantity of material to be transported, the size of the material, the transportation distance, and the mode of transport.

In the original scenario, the distance between the main materials and construction site is between 50 to $500 \mathrm{~km}$, depending of the type of material. To examine the impact induced by the location of local sourcing, an alternative carbon reduction strategy was examined (Table 3).

It is found that the single score can be reduce by $32 \mathrm{Kg} \mathrm{CO}_{2}$-e if the main materials are located $50 \mathrm{~km}$ from the construction site. In addition, the total embodied carbon emissions of transportation can be improved by about $30 \%$. It is clear that transportation indicates that local sourcing materials can significantly influence the environmental performance of embodied carbon emissions of the baseline scenario.

\section{Adoption of Biofuels}

Biodiesel is an environmental friendly alternative to fossil fuels. Biodiesel can be blended and used in many different concentrations when is implemented. The most common are: B6 to B20 (6\% to $20 \%$ biodiesel blended with petroleum diesel). B20 is a common biodiesel blend in North America, it is popular because it represents a good balance of cost, emissions, compatibility and does not require engine modifications. In the baseline scenario, petroleum diesel is used for all the on-site construction equipment. To investigate the improvement of environmental performance due to the adoption of biodiesel, a B20 mix blend was analyzed.

The results demonstrate that influence brought by B20 blend in the studied project is insignificant, only $0.1 \%$ of improvement in the overall score can be achieved. This result is primarily due to small use of fuels in on-site construction consequence of using prefabrication method. An important improvement could be achieved if B20 were used in transportation of building materials. 


\subsubsection{Low Carbon Materials}

As it can be seen in Section 3.2 the CFP of materials varies depending on the sort of the raw material composing, the source of material and mode of transport needed, carbon intensiveness of processing operations, carbon inventiveness of applicable construction, and distance to disposal sites. The material types on the embodied carbon buildings and the possibility of minimizing the carbon footprint of building through the selection of low carbon material is analyzed in this study.

In order to examine in depth, the performance of the assessed low-carbon materials, a comparative analysis was performed considering four different configurations of materials: cellulose insulation (recycled newsprint), cork flooring, light clay brick and ecological concrete. These data are referred to best performing commercialized and unconventional products whose low GHG emissions have been demonstrated.

Table 3 displays the low carbon strategies of embodied carbon emissions by altering design configurations. Colum "single reduction" shows the difference between $\mathrm{CO}_{2}$-e emissions produced by the reference building, built with conventional materials, and the hypothetical building constructed with low carbon criteria.

\section{Cellulose}

The results show that assessed cellulose is characterized by lower global warming potential in terms of $\mathrm{kg} \mathrm{CO}_{2}$-e per f.u. (0.73) in comparison with original insulator materials (EPS) in baseline scenario (2.92). The simulation results indicated that cellulose can potentially reduce by $0.8 \%$ overall carbon emissions. The main reduction to these values was due to the production of cellulose through grounding in a mill recycled papers, wood fibers and some chemical composites.

As shown in Table 3, the flooring system reduce $\mathrm{CO}_{2}$-e emissions by replacing conventional floor materials. The overall saving is about $3.1 \%$ for the use of hardwood flooring system. The global warming benefits can be attributed to the amount of carbon sequestered in hardwood flooring system that exceeds the total $\mathrm{CO}_{2}-\mathrm{e}$ emissions and hence, use of this flooring has a net climate change benefit of approximately $4.73 \mathrm{~kg} \mathrm{CO}$-e per f.u of installed flooring. In other words, atmospheric $\mathrm{CO}_{2}$-e sequestered in flooring boards during growth is more enough to offset the life cycle $\mathrm{CO}_{2}$-e emissions. It should be noticed that energy use for manufacturing hardwood systems also contributes to reduce $\mathrm{CO}_{2}$-e emissions due to the use of renewable and cleaner sources (wood fuel and hydro and nuclear-powered electricity).

\section{Unfired Clay Bricks}

The most sensitive factors for $\mathrm{CO}_{2}$-e reductions in selection of low carbon materials were the replacement of constituents of concrete and traditional bricks. In the case of bricks, clay building material plays a major role in improving the environmental efficiency and reduction of $\mathrm{CO}_{2}$-e emissions. Therefore, partial substitute for primary clay in the manufacture of traditional bricks were evaluated to quantify reduction of $\mathrm{CO}_{2}$-e emissions. A mix composition of unfired clay bricks (made from Portland cement and clay mixture) and GGBS (Table 2) was proposed as substitution of traditional clay in production of bricks. The benefits of using GGBS in unfired clay building brick include lower emissions of greenhouse gases and reduction in energy consumption in the extraction of conventional stabilizers.

The results demonstrate that unfired clay bricks have a higher strength potential of $\mathrm{CO}_{2}-\mathrm{e}$ reductions compared to traditional bricks. The total carbon reduction for the unfired clay bricks was estimated at around 3.6\% of total embodied carbon emissions of baseline scenario. The reduction carbon dioxide emissions for these bricks were estimated at $9.96 \mathrm{~kg} \mathrm{CO}_{2}$-e per f.u. The $\mathrm{CO}_{2}$-e emissions difference between both bricks may be attributed to the heating to high temperatures (900-1200 Celcius) in kilns firing the firing of conventional bricks, to give the final product strength and durability it requires to perform in service. Furthermore, firing clay-based material to such high-temperatures generally results in the release of several gases besides carbon dioxide. 


\section{Low Carbon Concrete}

A fractional replacement of cement in concrete with by-products such as fly-ash (FA) and (GGBFS) ground granulated blast furnace slag and natural aggregates with recycle crushed aggregate has been used to determine carbon reduction benefits because of the use of available recycled materials and by-products. The results show that the use of dereived-product and recyclates in concrete can reduce up to $3.8 \%$ (10.5 $\left.\mathrm{kg} \mathrm{CO}_{2}-\mathrm{e}\right)$ in comparison to the conventional concrete mix during the life cycle of the building. Nevertheless, GGBFS and FA both are by-products, but FA has lightly higher CFP reduction due to additional energy is used for grinding of granulated blast furnace slag. The concrete mixes containing 30\% cement substituted with FA present highest mitigation opportunity but other combinations with GGBFS can also add to substantial reduction opportunity.

$\mathrm{O}^{\prime}$ Brien [51] proposed that despite if FA is transported up to $10,000 \mathrm{~km}$ by truck, almost $50,000 \mathrm{~km}$ by rail and $55,000 \mathrm{~km}$ by sea for replacing cement in concrete, the net CFP will still be lower than that of tradtional concrete. Other type by-products offer flexible solutions, as polyethylene terephthalate (PET) could be used either as a constituent of concrete or as a replacement of polystyrene core [52].

Future research in this topic pointed out the possibility of replacing parts of cement in concrete production with wood ash. The method will produce both environmental and economic benefits and provide new opportunities to improving the quality of building materials. This means that both the industry and the environment can benefit greatly from recycling wood. However, this requires targeted research that strives to replace parts of the cement in concrete with wood ash.

Table 3. Overall reductions by implementing low carbon strategies in baseline scenario.

\begin{tabular}{|c|c|c|c|c|c|}
\hline Strategy & Actions & $\begin{array}{c}\text { Original Material } \\
\text { Emissions } \mathrm{Kg} \mathrm{CO}_{2} \text {-e } \\
\text { (Baseline) }\end{array}$ & $\begin{array}{c}\text { Single } \mathrm{Kg} \mathrm{CO}_{2}-\mathrm{e} \\
\text { (New Implementation) }\end{array}$ & $\begin{array}{c}\text { Single } \\
\text { Reduction } \\
\left(\mathrm{Kg} \mathrm{CO}_{2}-\mathrm{e}\right)\end{array}$ & $\begin{array}{c}\text { Overall Reduction \% } \\
\text { (Baseline }=275 \mathrm{~kg} \mathrm{CO}_{2} \text {-e) }\end{array}$ \\
\hline \multirow{2}{*}{$\begin{array}{l}\text { Low carbon } \\
\text { materials }\end{array}$} & $\begin{array}{l}\text { Cellulose insulation } \\
\text { (recycled newsprint) }\end{array}$ & 2.92 & 0.73 & 2.19 & $0.8 \%$ \\
\hline & $\begin{array}{l}\text { Hardwood flooring } \\
\text { system }\end{array}$ & 3.6 & -4.8 & 8.4 & $3.1 \%$ \\
\hline \multirow[b]{2}{*}{$\begin{array}{l}\text { Material } \\
\text { minimization }\end{array}$} & $\begin{array}{c}\text { Ratio waste of } \\
\text { Wood } 7 \%\end{array}$ & 14.52 & 12.05 & 2.46 & $0.9 \%$ \\
\hline & $\begin{array}{l}\text { Ratio waste of } \\
\text { Concrete } 7 \%\end{array}$ & None & None & None & None \\
\hline \multirow{2}{*}{$\begin{array}{l}\text { Local sources } \\
\text { and biofuels } \\
\text { adoption }\end{array}$} & $\begin{array}{l}\text { Local materials } \\
\text { distance } 50 \mathrm{~km}\end{array}$ & 37.52 & 5.42 & 32.09 & $11.7 \%$ \\
\hline & Mix B20 & 0.33 & 0.082 & 0.24 & $0.1 \%$ \\
\hline
\end{tabular}

\subsection{Comparison and Ranking of Carbon Reductions Strategies vs. Base Scenario}

One of the most important know-how necessary for the implementation of low GHG emissions in practice is the capacity to assess the effectiveness of approaches in the context of a real building.

Quantifying the CFP reductions achievable by the implementation of different low carbon reduction strategies gives keys insight into the design of low-climate-change residential constructions. This section combines the results of this study (baseline scenario) and the implementation analysis of factors influencing carbon emissions by mainly considering four strategies (Table 3).

The results of carbon reduction strategies show that overall reductions of life cycle GHG emissions are $106.5 \mathrm{~kg} \mathrm{CO}$-e $/ \mathrm{m}^{2}$ (38.8\%). Figure 5 shows the breakdown in terms of life cycle stages and carbon strategies wherein the implementation of recycled of wood waste (waste management) that 
accounted for the largest share $-11 \mathrm{~kg} \mathrm{CO}_{2}-\mathrm{e} / \mathrm{m}^{2}(14.6 \%)$ of the total CFP have been considered to be the principal hotspot. The local sourcing of materials and components (transportation) also reduce significant portion of GHG emissions $32 \mathrm{~kg} \mathrm{CO}_{2}-\mathrm{e} / \mathrm{m}^{2}(11.7 \%)$. In the production of building materials $\left(178.2 \mathrm{~kg} \mathrm{CO}-\mathrm{e} / \mathrm{m}^{2}\right)$, the use of clinker materials to produce cement $(3.8 \%)$ and light clay bricks $(3.6 \%)$ have been found to be the low carbon materials actions. All other actions such as cork flooring system, reduction of waste ratios, cellulose insulation and use of biofuels together contributed to the remaining reduction of GHG emissions $13.6 \mathrm{~kg} \mathrm{CO}$-e $/ \mathrm{m}^{2}(5 \%)$.

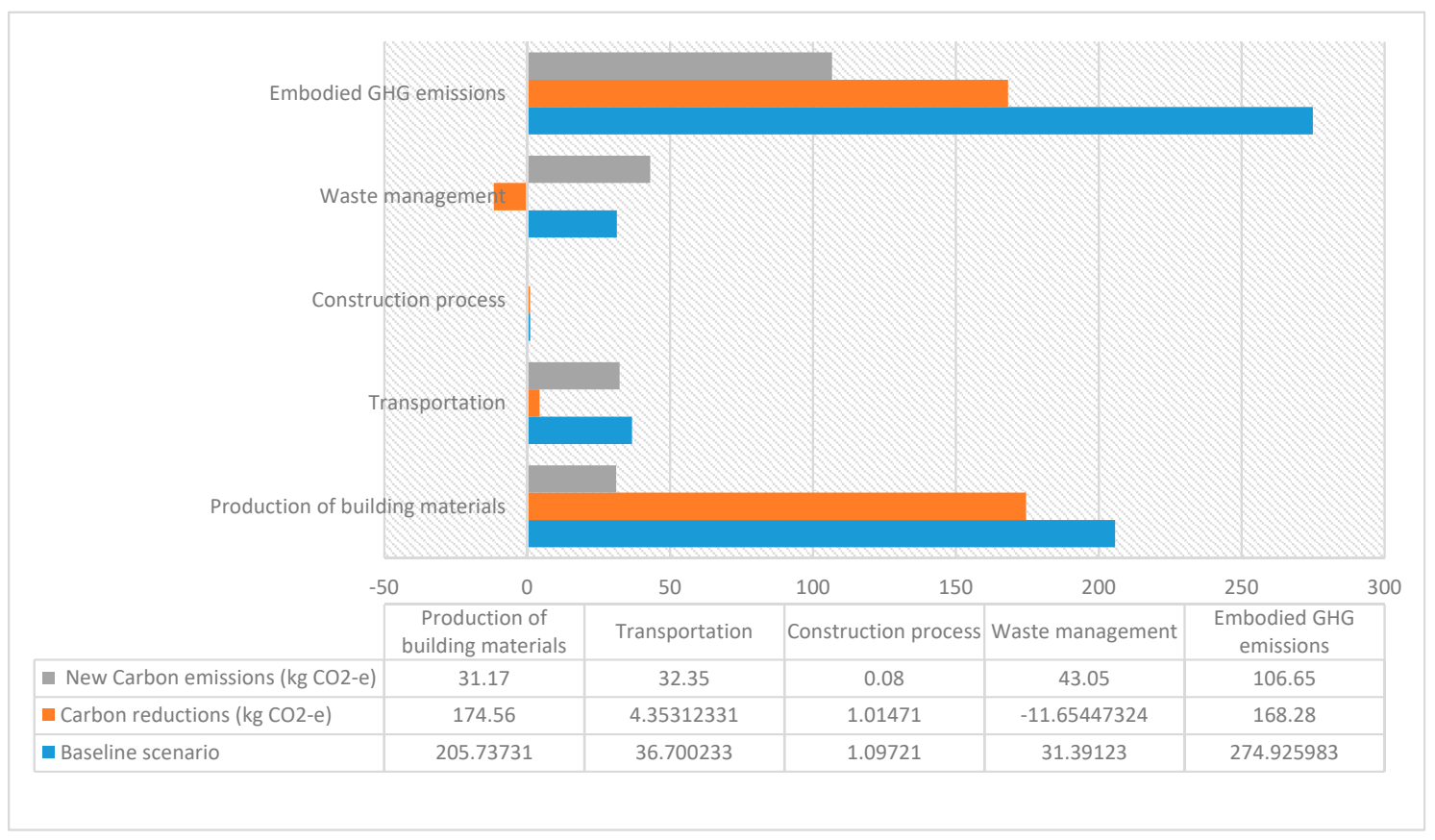

Figure 5. GHG emissions of baseline scenario, carbon reduction strategies and new carbon emissions $(\mathrm{kg} \mathrm{CO}-\mathrm{e})(\mathrm{COLOR})$.

\subsection{Carbon Reduction Strategies and Climate Change}

The impact of climate change on building fabrication and operation varies across building types, and the strength of variation deepens on the spatial time, temporal scale, and building technology. Buildings are sensitive to climate change, which influences energy demand and its profile. As climate warms, cooling demand increases and heating demand decreases, while passive cooling approaches become less effective. According Graham et al. [6] under a +3.7 scenario by 2100 , the worldwide reduction in heating energy demand due to climate change may reach $34 \%$ in 2100 , while cooling demand may increase by $70 \%$; with significant regional differences, e.g., $20 \%$ absolute reductions in heating demand in temperature Canada and Russia; cooling increasing by $50 \%$ in warmer regions and even higher increases in cold regions.

There is a wide range of opportunities to respond to changing climatic conditions in buildings, in this paper, the importance of carbon reduction strategies in building technology has been explored. Four carbon reduction strategies focus in building materials and processes in building fabrication were proposed and evaluated to contribute to climate change mitigation. As it was shown through the text, and analyzed by Wang [53], building technology plays an important role in determining building energy efficiency and consumption.

However, there is no consensus on establishing climate change adaptive buildings, but adoption of the low carbon strategies, such as, low carbon materials, reducing transportation and improving waste management, has a significantly positive impact to mitigate impact of climate change on the indoor environment. As pointed earlier, it can be found that the adoption and implementation of 
low carbon strategies is a pollution prevention method to reduce GHG emissions, which it can be translated into reduction of climate change impact as well as improve carbon-related performance of new buildings.

Mitigation effects may be different by development and urbanization level, climate conditions and building infrastructure. Contemporary strategies for adapting buildings to climate change still often emphasize increasing the physical resilience of building structure and fabric to extreme weather and climatic events, but this can lead to decreased functional adaptability and increased embodied energy and associated GHG emissions. The results presented in this work provide strong evidence to climate change mitigation due to building technology can positively be implemented as an approach to universal scope of climate policy, that connects long-term aspirations for sustainable development at the national level with demanding standards for sustainable buildings at the project level. However, as indicated Azevedo et al. [54] in the case of climate change mitigation actions, other factors should be considered, from past and ongoing policies at different government levels, climate change mitigation actions depend not solely on other local policies but also on the existing higher-level policies.

Government and private sector should not only adopt low carbon energy technology but also allocate more investment to it. Furthermore, the relation between climate change mitigation technologies and government performance depends on the effectiveness of the technologies available, and hence is likely to be dynamic in nature as the technologies evolve.

Another important aspect that concerns in building practitioners are that the cost and externalities, as pointed out Wang [53], they highlight that many firms are concerned that the climate change mitigation technologies and strategies may be associated with excessive costs and/or disruptions of business operations, and their burdens outweigh the operational and climate benefits. In this sense, Poveda and Young [55] argued that if it pays to be green, constructers firms can achieve win-win in both environmental and operational dimensions, because environmental pressures provide constructors firms with an opportunity to improve efficiency and competitiveness through environmental innovations in processes and products.

In the other hand, it is noteworthy that stakeholders involved in buildings should take tasks to the government, they must urge the manufacturers of materials to use Environmental Program Declarations (EDP), verified by independent organizations that provide standardized information based on the life cycle analysis of the real impact of every product. This could stimulate competition among manufactures and contractors in order to produced more ecofriendly products, which would be more highly regarded by the construction sector as opposed to other products without EPDs, as they would offer a new range of buildings that really have a low environmental impact, not only due to their low final energy consumption, but also due to the reduced impact of the materials that comprise them. Therefore, there would be exact information on the impact of each product, which would easy a correct evaluation of the impact of a building from a life cycle framework. Nevertheless, it is worth noting that there are as yet limited empirical studies of low carbon strategies implemented in current buildings, so care should be taken when interpreting the findings within specific contexts.

Additionally, new research is needed and focusing on the issue of how a building would be made more resilient. While reducing embodied energy would be a worthwhile strategy to pursue for long term benefits, the reality is that buildings are already feeling the effects of climate change right now.

\section{Conclusions}

A comprehensive evaluation of carbon reduction strategies to estimate and minimize the CFP emissions of buildings was presented in this work. According to the obtained environmental impacts, these conclusions can be drawn as follows:

- The results of this study support the positive use of prefabricated approach in buildings as an alternative construction method based on wood-frame-materials in Quebec. 
- The above results imply that from the perspective of overall performance, low-carbon strategies are beneficial to climate change mitigation technology that can balance operational performance and environmental performance to achieve the zero emissions buildings'.

- By using the $\mathrm{CO}_{2}$-e emissions as global indicator, the $\mathrm{CC}$ reduction per $\mathrm{m}^{2}$ floor area in baseline scenario can reach up to $25 \%$ fewer emissions than traditional buildings built with steel or concrete.

- During the life-cycle of baseline scenario, total embodied carbon emissions of $275 \mathrm{~kg} \mathrm{CO}_{2}$-e was calculated. The fabrication of building material phase contributed the most (75\%) to the carbon emissions, while transportation (13\%), construction $(1 \%)$ and waste management $(11 \%)$ contribute to $25 \%$.

- The four actions implemented have an environmental benefit in reducing $\mathrm{CO}_{2}$-e emissions. The analysis of low carbon strategies showed an overall carbon reduction approximately $104 \mathrm{~kg}$ $\mathrm{CO}_{2}$-e $(38 \%)$ in comparison to baseline scenario.

- The $\mathrm{CO}_{2}$-e emissions reduction in the building sector as climate change mitigation is perfectly feasible by following different working lines. The four actions implemented have an environmental benefit in reducing GHG emissions. The particleboard production scenario has a greater environmental benefit when considering temporary carbon storage. The ranking of actions can be stablished as follows:

1. Use of particle board production using wood wastes $(14.6 \%)$

2. Use of local source for materials and components (11.7\%)

3. Substitution of concrete composition (3.8\%)

4. Use of light clay bricks (3.6\%)

5. Use of hardwood flooring system (3.1\%)

6. Reduction of rate wastes (wood, concrete and steel) $(1 \%)$

7. Use of cellulose insulation $(0.8 \%)$

8. Use of B20 blend as fuel for on-site machines. (0.1\%)

It was demonstrated that use of wood-based building materials can contribute to a sustainable built environment based on resource-efficient systems with low environmental impact. Wood building products from sustainably managed forests are a renewable resource that can provide multiple benefits during their life cycle. In addition to their structural and architectural use within a building, the life cycle wood product chain produces significant quantities of biomass co-products that can be used as a carbon storage to reduce GHG emissions. The use of forest resources in the built environment can play an important role in a long-term strategy for sustainable development and climate change mitigation.

Reuse of construction materials can lead to significant resource savings together with other environmental benefits from a reduction in waste disposed of in landfill and the energy required for the production of virgin materials. The recyclability of materials and implementation of a recycling strategy may affect the embodied carbon of the buildings in different ways and should be considered in the selection of components for low-carbon strategies.

Due to the demand for large number of buildings, current approach could significantly reduce global warming impacts associated with the construction and assembly of building industry that can contribute to Quebec's commitment of GHG emissions reduction targets by 2050. Nevertheless, it is important to point out that the main research limitation of this study is the use of hypothetical data used to calculate the low carbon reductions strategies, although, this approach could help designers, architects and engineers to move forward low carbon reductions strategies in order to make these implementations a common practice in building sector.

A future priority is to facilitate learning and continual improvement throughout this sort of projects, for example by comparing analysis of case studies in collaboration with industry partners for evaluating outcomes. Based on this analysis, uniform low carbon strategies should be developed and integrated into the broader development of buildings. It is necessary to achieve a better understanding 
of trends and their alignment with advances in other related disciplines. So, it is important to develop an environmental tool that could help engineers, developers and designers to estimate the CFP and embodied energy increasing benefits of the use of alternative carbon systems and by-products, particularly wood products.

Author Contributions: A.P.-R. was the first author on the manuscript and carried out the main data analysis. He was the principal investigator running the carbon footprint evaluation. B.A. was the second author and contributed substantially to the manuscript. P.B. was involved in the supervision of the project and the main supervisor of the project. He helped the project conception and helped to revise the manuscript.

Acknowledgments: The authors are greatful to Natural Sciences and Engineering Research Council of Canada (NSERC) for supporting of this research as well as the industrial partners of the NSERC industrial chair on eco-responsible wood construction (CIRCERB).

Conflicts of Interest: The authors declare no conflict of interest

\section{References}

1. IPCC. Climate Change 2013: The Physical Science Basis. Contribution of Working Group I to the Fifth Assessment Report of the Intergovernmental Panel on Climate Change; Cambridge: New York, NY, USA, 2013.

2. UNEP. The Emissions Gap Report 2016. The Emissions Gap Report 2016. United Nations Environment Programme (UNEP); United Nations Environment Programme: Nairobi, Kenya, 2016.

3. Dechezleprêtre, A.; Glachant, M.; Haščič, I.; Johnstone, N.; Ménière, Y. Invention and transfer of climate change-mitigation technologies: A global analysis. Rev. Environ. Econ. Policy 2011, 5, 109-130. [CrossRef]

4. Qin, Z.; Zhuang, Q.; Cai, X.; He, Y.; Huang, Y.; Jiang, D.; Lin, E.; Liu, Y.; Tang, Y.; Wang, M.Q. Biomass and biofuels in China: Toward bioenergy resource potentials and their impacts on the environment. Renew. Sustain. Energy Rev. 2017. [CrossRef]

5. Zhang, D.; Wang, J.; Lin, Y.; Si, Y.; Huang, C.; Yang, J.; Huang, B.; Li, W. Present situation and future prospect of renewable energy in China. Renew. Sustain. Energy Rev. 2017, 76, 865-871. [CrossRef]

6. Graham, P.; Henry Abanda, F.; Korytarova, K.; Ürge-Vorsatz, D.; Zain Ahmed, A.; Akbari, H.; Bertoldi, P.; Cabeza, L.F.; Eyre, N.; Gadgil, A.; et al. Buildings. In Climate Change 2014: Mitigation of Climate Change. Contribution of Working Group III to the Fifth Assessment Report of the Intergovernmental Panel on Climate Change; Volker Krey: Cambridge, UK; New York, NY, USA, 2014.

7. Roh, S.; Tae, S.; Suk, S.J.; Ford, G. Evaluating the embodied environmental impacts of major building tasks and materials of apartment buildings in Korea. Renew. Sustain. Energy Rev. 2017, 73, 135-144. [CrossRef]

8. Shadram, F.; Johansson, T.D.; Lu, W.; Schade, J.; Olofsson, T. An integrated BIM-based framework for minimizing embodied energy during building design. Energy Build. 2016, 128, 592-604. [CrossRef]

9. Yeo, D.; Gabbai, R.D. Sustainable design of reinforced concrete structures through embodied energy optimization. Energy Build. 2011, 43, 2028-2033. [CrossRef]

10. Thomark, C. Environmental Analysis of a Building with Reused Building Materials. Available online: http:/ / muep.mau.se/handle/2043/9844 (accessed on 31 July 2018).

11. Akbarnezhad, A.; Xiao, J. Estimation and Minimization of Embodied Carbon of Buildings: A Review. Buildings 2017, 7, 5. [CrossRef]

12. Jaillon, L.; Poon, C.S. Life cycle design and prefabrication in buildings: A review and case studies in Hong Kong. Autom. Constr. 2014, 39, 195-202. [CrossRef]

13. Tam, V.W.Y.; Fung, I.W.H.; Sing, M.C.P.; Ogunlana, S.O. Best practice of prefabrication implementation in the Hong Kong public and private sectors. J. Clean. Prod. 2015, 109, 216-231. [CrossRef]

14. Cao, X.; Li, X.; Zhu, Y.; Zhang, Z. A comparative study of environmental performance between prefabricated and traditional residential buildings in China. J. Clean. Prod. 2015, 109, 131-143. [CrossRef]

15. Sambito, M.; Freni, G. LCA methodology for the quantification of the carbon footprint of the integrated urban water system. Water 2017, 9. [CrossRef]

16. Wiedmann, T.; Minx, J. Ecological Economics; Pertsova, C., Ed.; Nova Science Publishers, Inc.: New York, NY, USA, 2007; ISBN 6312317269.

17. Laurent, A.; Olsen, S.I.; Hauschild, M.Z. Carbon footprint as environmental performance indicator for the manufacturing industry. CIRP Ann.-Manuf. Technol. 2010, 59, 37-40. [CrossRef] 
18. Parravicini, V.; Svardal, K.; Krampe, J. Greenhouse Gas Emissions from Wastewater Treatment Plants. Energy Procedia 2016, 97, 246-253. [CrossRef]

19. ISO. ISO 14067:2013 Greenhouse gases-Carbon footprint of products-Requirements and guidelines for quantification and communication. Int. Organ. Stand. 2013, 64. [CrossRef]

20. International Organization for Standardisation ISO. 1440 Environmental management-life cycle assessment-principles and framework. Lond. Br. Stand. Inst. 2006. [CrossRef]

21. La Société d'habitation du Québec Prject de Démonstration. Available online: http:/ /www.webcitation.org/ 71E6BHrRd (accessed on 10 October 2017).

22. Canada, G. Of Weahter Information in Canada. Available online: http://www.webcitation.org/71IvZFNwk (accessed on 10 October 2017).

23. Zhu, H.; Hong, J.; Shen, G.Q.; Mao, C.; Zhang, H.; Li, Z. The exploration of the life-cycle energy saving potential for using prefabrication in residential buildings in China. Energy Build. 2018, 166, 561-570. [CrossRef]

24. Pujadas-Gispert, E.; Sanjuan-Delmás, D.; Josa, A. Environmental analysis of building shallow foundations: The influence of prefabrication, typology, and structural design codes. J. Clean. Prod. 2018, 186, 407-417. [CrossRef]

25. Mao, C.; Shen, Q.; Shen, L.; Tang, L. Comparative Study of Greenhouse Gas Emissions between Off-Site Prefabrication and Conventional Construction Methods: Two Case Studies of Residential Projects. Available online: http:/ / ira.lib.polyu.edu.hk/handle/10397/25904 (accessed on 31 July 2018).

26. Anand, C.K.; Amor, B. Recent developments, future challenges and new research directions in LCA of buildings: A critical review. Renew. Sustain. Energy Rev. 2017, 67, 408-416. [CrossRef]

27. Abd Rashid, A.F.; Yusoff, S. A review of life cycle assessment method for building industry. Renew. Sustain. Energy Rev. 2015, 45, 244-248. [CrossRef]

28. Wernet, G.; Bauer, C.; Steubing, B.; Reinhard, J.; Moreno-Ruiz, E.; Weidema, B. The ecoinvent database version 3 (part I): Overview and methodology. Int. J. Life Cycle Assess. 2016, 21, 1218-1230. [CrossRef]

29. Société d'habitation du Québec (SHQ). Life Cycle Assessment of Residencial Buildings; SHQ: Quebec, QC, Canada, 2016.

30. International Organization for Standardization (ISO). ISO 14040:2006_Environmental Management-Life Cycle Assessment-Principles and Framework; International Organization for Standardization: Geneva, Switzerland, 2006.

31. 2006 IPCC Guidelines for National Greenhouse Gas Inventories. Available online: https:/ /www.ipcc-nggip. iges.or.jp/public/2006gl/ (accessed on 31 July 2018).

32. Cherubini, F.; Peters, G.P.; Berntsen, T.; Strømman, A.H.; Hertwich, E. $\mathrm{CO}_{2}$ emissions from biomass combustion for bioenergy: Atmospheric decay and contribution to global warming. GCB Bioenergy 2011, 3, 413-426. [CrossRef]

33. Bright, R.M.; Cherubini, F.; Strømman, A.H. Climate impacts of bioenergy: Inclusion of carbon cycle and albedo dynamics in life cycle impact assessment. Environ. Impact Assess. Rev. 2012, 37, 2-11. [CrossRef]

34. Schiavoni, S.; D'Alessandro, F.; Bianchi, F.; Asdrubali, F. Insulation materials for the building sector: A review and comparative analysis. Renew. Sustain. Energy Rev. 2016, 62, 988-1011. [CrossRef]

35. Mahalle, L.; Lavoie, P.; Meek, P.; McDonald, J. A Comparative Life Cycle Assessment of Canadian Hardwood Flooring with Alternative Flooring Types. Available online: http://docplayer.net/9017155A-comparative-life-cycle-assessment-of-canadian-hardwood-flooring-with-alternative-flooring-typesacknowledgements.html (accessed on 31 July 2018).

36. Oti, J.E.; Kinuthia, J.M. Stabilised unfired clay bricks for environmental and sustainable use. Appl. Clay Sci. 2012, 58, 52-59. [CrossRef]

37. Lawania, K.; Sarker, P.; Global, W. Warming Implications of the Use of By-Products and Recycled Materials in Western Australia's Housing Sector. Materials 2015, 8, 6909-6925. [CrossRef]

38. Blengini, G.A. Life cycle of buildings, demolition and recycling potential: A case study in Turin, Italy. Build. Environ. 2009, 44, 319-330. [CrossRef]

39. Kim, M.H.; Song, H.B. Analysis of the global warming potential for wood waste recycling systems. J. Clean. Prod. 2014, 69, 199-207. [CrossRef]

40. Dong, Y.H.; Ng, S.T. A life cycle assessment model for evaluating the environmental impacts of building construction in Hong Kong. Build. Environ. 2015, 89, 183-191. [CrossRef] 
41. Canadian Wood Council (CWC). Sustainability and Life Cycle Analysis for Residential Buildings; Canadian Wood Council: Quebec, QC, Canada, 2010.

42. Lessard, Y. Modélisation de L'influence de la Sélection des Matériaux sur le Profil Environnemental du Cycle de vie D'un Bâtiment à Bureaux: Évaluation Critique de Leed V4; Universite de Sherbrooke: Sherbrooke, QC, Canada, 2017.

43. Zabalza Bribián, I.; Capilla, A.V.; Usón, A.A. Life cycle assessment of building materials: Comparative analysis of energy and environmental impacts and evaluation of the eco-efficiency improvement potential. Build. Environ. 2011, 46, 1133-1140. [CrossRef]

44. Güereca, L.P.; Torres, N.; Juárez-López, C.R. The co-processing of municipal waste in a cement kiln in Mexico. A life-cycle assessment approach. J. Clean. Prod. 2015, 107, 741-748. [CrossRef]

45. Dodoo, A.; Gustavsson, L.; Sathre, R. Lifecycle primary energy analysis of low-energy timber building systems for multi-storey residential buildings. Energy Build. 2014, 81, 84-97. [CrossRef]

46. Pons, O.; Wadel, G. Environmental impacts of prefabricated school buildings in Catalonia. Habitat Int. 2011, 35, 553-563. [CrossRef]

47. Kulshrestha, S. Resins for Construction. Available online: https://www.buildotechindia.com/resins-forconstruction/ (accessed on 3 May 2017).

48. Kumbhar, S.; Kulkarni, N.; Rao, A.B.; Rao, B. Environmental Life Cycle Assessment of Traditional Bricks in Western Maharashtra, India. Energy Procedia 2014, 54, 260-269. [CrossRef]

49. Renzulli, P.; Notarnicola, B.; Tassielli, G.; Arcese, G.; Di Capua, R. Life Cycle Assessment of Steel Produced in an Italian Integrated Steel Mill. Sustainability 2016, 8, 719. [CrossRef]

50. Aye, L.; Ngo, T.; Crawford, R.H.H.; Gammampila, R.; Mendis, P. Life cycle greenhouse gas emissions and energy analysis of prefabricated reusable building modules. Energy Build. 2012, 47, 159-168. [CrossRef]

51. O’Brien, K.R.; Ménaché, J.; O’Moore, L.M. Impact of fly ash content and fly ash transportation distance on embodied greenhouse gas emissions and water consumption in concrete. Int. J. Life Cycle Assess. 2009, 14, 621-629. [CrossRef]

52. Foti, D. Preliminary analysis of concrete reinforced with waste bottles PET fibers. Constr. Build. Mater. 2011, 25, 1906-1915. [CrossRef]

53. Wang, C.; Zhao, D.; Tsutsumi, A.; You, S. Sustainable energy technologies for energy saving and carbon emission reduction. Appl. Energy 2017, 194, 223-224. [CrossRef]

54. Azevedo, I.; Leal, V.M.S. Methodologies for the evaluation of local climate change mitigation actions: A review. Renew. Sustain. Energy Rev. 2017, 79, 681-690. [CrossRef]

55. Poveda, C.A.; Young, R. Potential benefits of developing and implementing environmental and sustainability rating systems: Making the case for the need of diversification. Int. J. Sustain. Built. Environ. 2015, 4, 1-11. [CrossRef]

(c) 2018 by the authors. Licensee MDPI, Basel, Switzerland. This article is an open access article distributed under the terms and conditions of the Creative Commons Attribution (CC BY) license (http://creativecommons.org/licenses/by/4.0/). 